\title{
A geochemical model for coral reef formation
}

\author{
T. Nakamura $\cdot$ T. Nakamori
}

Received: 9 February 2007/ Accepted: 21 May 2007/Published online: 10 July 2007

(C) Springer-Verlag 2007

\begin{abstract}
The conspicuous growth of a reef crest and the resulting differentiation of reef topography into a moat (shallow lagoon), crest and slope have long attracted the interest of scientists studying coral reefs. A geochemical model is here proposed for reef formation, taking into account diffusion-limited and light-enhanced calcification. First, to obtain data on net photosynthesis and calcification rates in the field, a typical coral community was cultured in situ on a reef flat. Using these data, equations including parameters for calcification were then developed and applied in computer simulations to model the development over time of reef profiles and the diffusion of carbon species. The reef topography simulated by the model was in general agreement with reef topography observed in nature. The process of reef growth as shown by the modeling was as follows. Increases in the shore-to-offshore gradients of the concentrations of carbonate species result from calcification by reef biota, giving a lower rate of growth on near-shore parts of the reef than on those further offshore. As a result, original topography is diversified into moat and reef crest for the first time. Reef growth on the reef crest is more rapid than in the inshore moat area, because more light is available at the crest. Reef growth on the nearshore side of the reef is further inhibited by damming of carbon-rich seawater on the seaward side of the reef by
\end{abstract}

Communicated by Geology Editor B. Riegl.

T. Nakamura $(\bowtie) \cdot$ T. Nakamori Institute of Geology and Paleontology, Graduate School of Science, Tohoku University, Aobayama, Sendai 980-8578, Japan

e-mail: takachi@dges.tohoku.ac.jp the reef crest. Over time, the topographic expression of the reef crest and moat becomes progressively more clearly defined by these geochemical processes.

Keywords Calcification · Photosynthesis - Reef formation $\cdot$ Simulation

\section{Introduction}

The upper parts of well-developed coral reefs have a unique topography that differs markedly from those of other marine coastal environments. Most of the fringing reefs of the Ryukyu Islands, for example, are characterized by both a convex "reef crest" and a concave "moat" (shallow lagoon). These structures are common, differing only in scale, not only on fringing reefs but also on barrier reefs and atolls. Understanding why such topography is regularly formed is one of the most important unresolved problems in coral reef geology.

Growth histories of coral reefs in the Ryukyu Islands from the Holocene to the present have been reconstructed based on core samples from both raised coral reefs in uplifted areas, and on recent reef flats in more stable regions (Konishi et al. 1983; Takahashi et al. 1988; Kan and Hori 1993; Yonekura et al. 1994; Kan et al. 1995, 1997; Yamano et al. 2001b). Like coral reefs in the tropics, those in the Ryukyu Islands grew remarkably during the postglacial sea-level rise and the ensuing stillstand. Most Japanese Holocene reefs began to develop from around 10,000 years before present (BP), which is later than the time of initiation of typical reefs in the tropics. Catch-up reef growth dominated from 10,000 to 6,000 years BP because of rapid sea-level rise. The reef crest structures grew quickly after this stage and caught up with the rate of sea-level change 
during the period from 6,000 to 4,000 years BP (Takahashi et al. 1988; Yamano et al. 2001a). Construction of a shallow reef crest diversified the reef environment by the development of a wave-affected fore-reef, and a calm back-reef with a depressed topography in the form of a moat (Takahashi et al. 1988; Yamano et al. 2001a). This growth history suggests that reef crests grow rapidly during periods of sea-level rise. Montaggioni (2005) reported this peculiar pattern not only from the Ryukyu Islands but also from the other parts of coral reef areas, e.g., Pointe-auSable reef, Mauritius, Indian Ocean (Montaggioni and Faure 1997), Koror barrier reef, Palau, Western Pacific (Kayanne et al. 2002), One Tree Reef, Central Great Barrier Reef (Marshall and Davies 1982), Central area, Lord Howe Island, Tasman Sea, Western Pacific (Kennedy and Woodroffe 2000), and Punta Islotes fringing reef, Costa Rica, Eastern Pacific (Cortés et al. 1994).

The growth rate of reef crests and the development of other morphological characteristics of the reef systems would have been affected by calcification of coral reef biota, because the reef framework is made of carbonate skeletons precipitated by them. Recent scientific work has shown that calcification can be defined by a simple function relating to environmental parameters, such as light intensity (Chalker 1981), and available chemical components (Gattuso et al. 1998a; Marubini and Thake 1999; Odhe and van Woesik 1999; Leclercq et al. 2000, 2002; Langdon et al. 2000). This study builds on that work, and proposes a model for coral reef growth that is based on calcification and other chemical and physical processes in the reef environment.

It is important that the effect of "light-enhanced calcification" by hermatypic corals (Goreau and Goreau 1959; Barnes and Chalker 1990) is included in the model. This phenomenon has been reported on the basis of observations carried out at different spatial scales; for example, a coral colony (Goreau 1959), a coral community (Suzuki et al. 1995), and a complete reef (Barnes and Devereux 1984). Hermatypic corals are well known for their symbiosis with the dinoflagellate algae zooxanthellae. Incubation experiments suggest that photosynthesis by zooxanthellae enhances coral calcification (Goreau 1959; Gattuso et al. 1999), although the calcification does not have such effect on the photosynthesis under inhibited calcification (Yamashiro 1995; Gattuso et al. 2000). The photosynthesis of marine organisms is expressed by the following two equations:

$$
\begin{aligned}
& \mathrm{HCO}_{3}^{-} \rightarrow \mathrm{CO}_{2}+\mathrm{OH}^{-} \\
& \mathrm{CO}_{2}+\mathrm{H}_{2} \mathrm{O} \rightarrow\left[\mathrm{CH}_{2} \mathrm{O}\right]+\mathrm{O}_{2},
\end{aligned}
$$

and the calcification process can be expressed as follows:
$\mathrm{HCO}_{3}^{-} \rightarrow \mathrm{CO}_{3}^{2-}+\mathrm{H}^{+}$

$\mathrm{Ca}^{2+}+\mathrm{CO}_{3}^{2-} \rightarrow \mathrm{CaCO}_{3}$.

The production of $\mathrm{OH}^{-}$during photosynthesis, as shown in Eq. (1), and of $\mathrm{H}^{+}$during calcification, as shown in Eq. (3), is significant, as discussed subsequently.

Gattuso et al. (1999) reviewed investigations into photosynthesis-enhanced calcification by hermatypic corals and pointed out that the endodermal cell layer secretes $\mathrm{OH}^{-}$ during photosynthesis and generates a $\mathrm{pH}$ gradient across the epithelial layer, with the endodermal side being alkaline. This $\mathrm{OH}^{-}$can neutralize the $\mathrm{H}^{+}$produced during coral calcification and accelerate the calcification. Although the interaction between calcification and endosymbiont photosynthesis remains unclear (Gattuso et al. 2000), it is generally accepted that photosynthesis and light availability are the main factors controlling the rate of calcification.

Another factor controlling the calcification rate is the degree of aragonite saturation, $\Omega_{\text {arag }}\left(=\left[\mathrm{Ca}^{2+}\right]\left[\mathrm{CO}_{3}^{2-}\right] / K_{\text {arag }}\right.$, where $K_{\text {arag }}$ is the solubility product for aragonite), or $\left[\mathrm{CO}_{3}^{2-}\right]$, which is the dominant variable in the expression of $\Omega_{\text {arag. }}$. The dependency of the calcification rate on $\Omega_{\text {arag }}$ or $\left[\mathrm{CO}_{3}^{2-}\right]$ has been elucidated in laboratory experiments using the hermatypic corals Stylophora pistillata (Gattuso et al. 1998a), Porites compressa (Marubini and Atkinson 1999), and Porites porites (Marubini and Thake 1999). This phenomenon has also been observed in coral reef communities (Suzuki et al. 1995; Langdon et al. 2000; Leclercq et al. 2000, 2002). Langdon et al. (2000) concluded that the $\Omega_{\text {arag }}$ of the seawater can be correlated to the calcification rate of coral reef community in the Biosphere 2 ocean during short term (days) and long term (months to years). This result also supported that coral reef calcification is controlled by $\Omega_{\text {arag }}$ (or $\left[\mathrm{CO}_{3}^{2-}\right]$ ).

Metabolism within active coral reef communities changes the composition of seawater carbonate species. The calcification reduces both the total amount of carbon and the alkalinity, resulting in a decrease of $\left[\mathrm{CO}_{3}^{2-}\right]$ and an increase in the fugacity of $\mathrm{CO}_{2}\left(f \mathrm{CO}_{2}\right)$ in seawater owing to a fall of $\mathrm{pH}$. Gradients of $\mathrm{pH}$, total carbon, total alkalinity, and $f \mathrm{CO}_{2}$ were observed along transects across lagoons of the Palau Barrier Reef, Majuro Atoll, South Male Atoll (Suzuki et al. 1997; Suzuki and Kawahata 1999), Great Barrier Reef (Kawahata et al. 2000), and Palau barrier reef (Watanabe et al. 2006). It is therefore possible that the rate of calcification is limited by the supply of $\mathrm{CO}_{3}^{2-}$ from the open ocean, because the $\left[\mathrm{CO}_{3}^{2-}\right]$ in seawater is reduced by calcification, and the calcification is reduced by the decrease of $\left[\mathrm{CO}_{3}^{2-}\right]$.

The above review shows that the primary factors controlling reef growth might be geochemical processes, such as diffusion of carbonate species and light-enhanced 
calcification. Previous authors, however, have not verified their ideas by using field data or computer simulations. Reconstruction of the growth history of reef topography and the distribution of carbonate species in seawater by using finite difference modeling methods are therefore an important advance.

The aims of this study were to test the hypothesis that basic Holocene reef morphological development can be explained by a limited set of linked fundamental process: light-enhanced calcification, eddy diffusion on chemical constituents in seawater, carbonate equilibrium, etc. To this end, this paper (1) proposes equations for photosynthesis and calcification rates of a coral community using data from in situ incubation on a coral reef, (2) constructs a geochemical model for coral reef formation incorporating reef growth and diffusion of inorganic carbon species, and (3) executes computer simulations of that model.

\section{Materials and methods}

\section{Study area}

The Shiraho coral reef, which is south of Ishigaki Island $\left(24^{\circ} 22^{\prime} \mathrm{N}, 124^{\circ} 15^{\prime} \mathrm{E}\right)$ in the southwestern part of the Ryukyu Islands, Japan (Fig. 1), was selected for this study. The climate of Ishigaki Island is subtropical. Most of the coast of Ishigaki Island is surrounded by fringing reefs that have well-developed reef-crest and moat topography. These features are also evident off the Shiraho area, where topographic zones are arranged parallel to the coastline. The width of the reef within the study area is about $700 \mathrm{~m}$ in the north and $1,000 \mathrm{~m}$ in the south, which is about the average width of Japanese coral reefs. Nakamori (1986) reported a zonation of coral communities concordant with topographic trends at this site.

Topography and coral communities

The characteristic reef flat (near shore) and reef slope (off shore) at the study site has been described in detail in a previous study (Nakamura and Nakamori 2006). The reef flat is a horizontal plane with patches of coral and depressions shallower than $3 \mathrm{~m}$ depth. The reef slope is a steeply inclined plane extending from sea level to a depth of $30 \mathrm{~m}$ off Ishigaki Island. The reef flat can be divided into four subunits: a moat (shallow lagoon), an inner reef flat, a reef crest, and an outer reef flat (Fig. 2a).

Nakamura and Nakamori (2006) reported six coral communities in the study area (Fig. 2b-d), and, on the basis of cluster analysis, named them the "massive Porites Goniastrea aspera community", "Montipora stellata community", "branching Acropora community", "Montipora digitata community", "encrusting Acropora community", and "Pocillopora verrucosa - tabular Acropora community".

\section{Experimental design}

For in situ incubation, a sealed aquarium (Fig. 3) was settled on the floor of the moat at a distance of $400 \mathrm{~m}$ from the shore (2.43 $\mathrm{m}$ deep) on the transect (Fig. 1). The acrylic aquarium was a cuboid shape of $0.6 \mathrm{~m}$ length, $0.6 \mathrm{~m}$ width, and $0.3 \mathrm{~m}$ height. The seawater inside the aquarium could be exchanged by releasing the upper part of the aquarium from its base, to which it was attached by eight locks. Two rubber gloves were included in the design of the aquarium to allow access to enclosed equipment (Fig. 3).
Fig. 1 Site of the aquarium used for in situ incubation on the cross-reef transect of Nakamura and Nakamori (2006) at Shiraho, Ishigaki Island. Aerial photograph (95 ISHIGAKI C15-34) acquired from the Geographical Survey Institute, Ministry of Construction, Japan

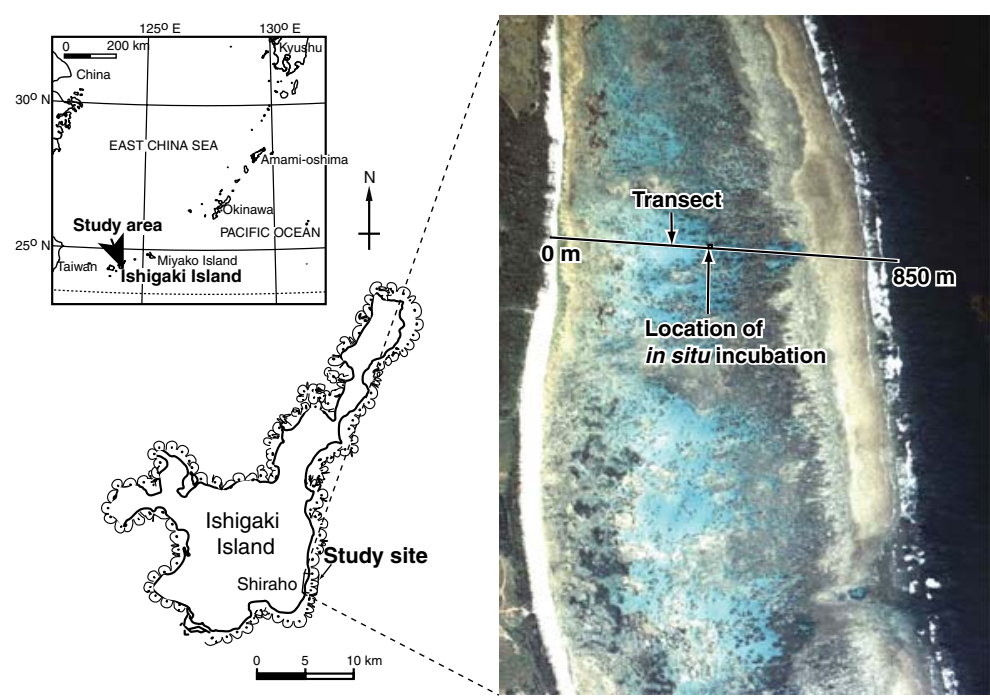


Fig. 2 Cross sections along the cross-reef transect of the fringing reef at Shiraho (modified from Nakamura and Nakamori 2006). a Depth profile and topographic zonation, b coverage of corals, c relative abundance of coral species, and $\mathbf{d}$ zonation of coral communities
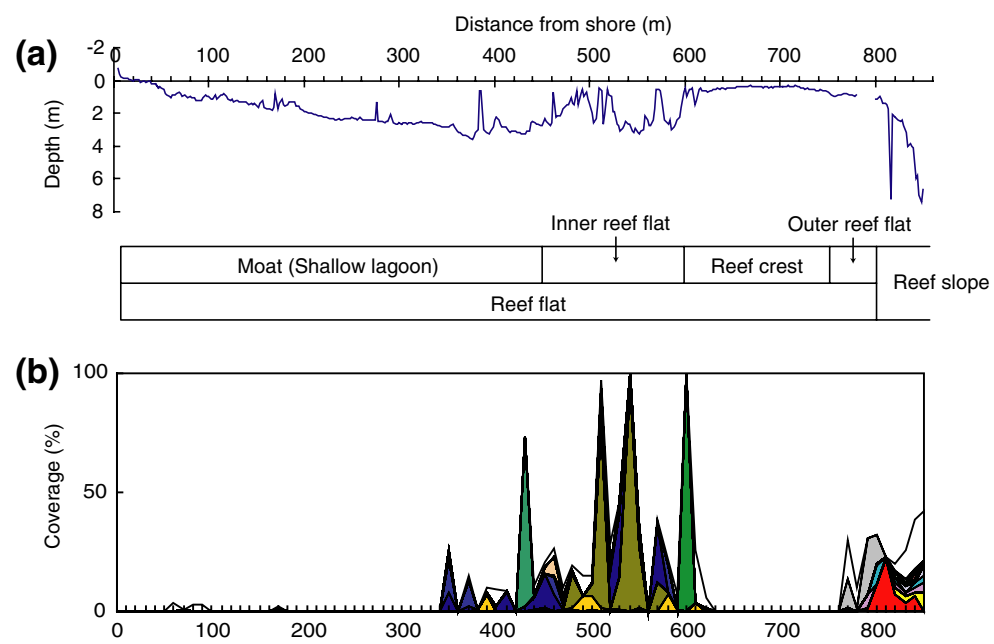

(c)

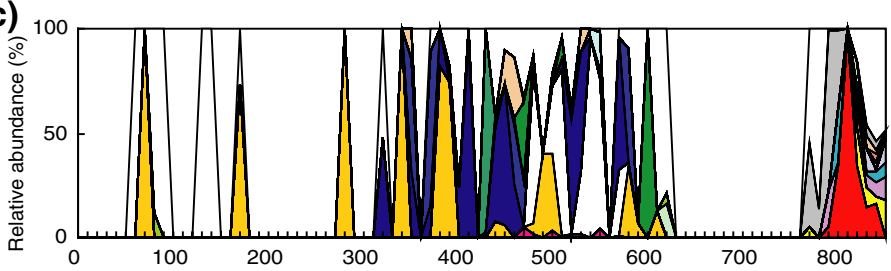

(d)

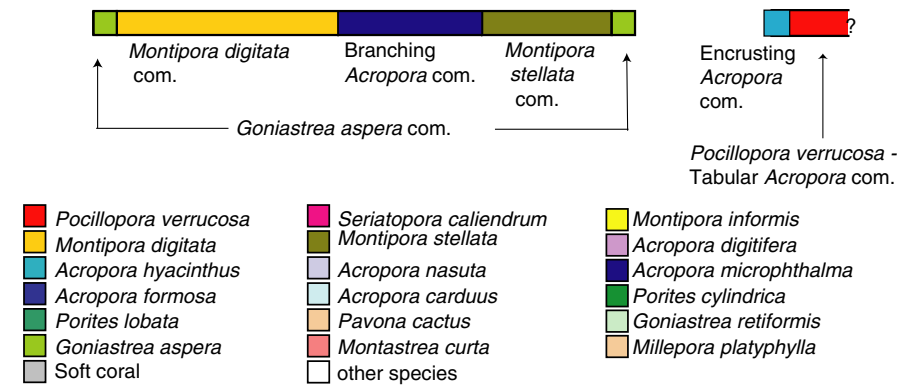

The coverage of the hermatypic corals inside the aquarium was estimated from a sketch and some underwater photographs. Total alkalinity $\left(A_{\mathrm{T}}\right)$ and $\mathrm{pH}$ were measured to determine net photosynthesis and calcification rates $\left(P_{\mathrm{n}}\right.$ and $\left.G\right)$ of the coral community. Photon flux density $\left(F_{\mathrm{P}}\right)$ and the practical salinity of the seawater were measured simultaneously during the experiment. In some cases, the original author's symbols have been modified to be consistent with notation adopted. All symbols are listed in Table 1.

The $\mathrm{pH}$ was reconstructed from voltage by using a pHC2001 electrode and PHM240 pH meter (Radiometer Analytical, France). The electrode was calibrated with NBSscale buffer solutions. Seawater $A_{\mathrm{T}}$ was obtained using the $\mathrm{pH}$ method of Culberson et al. (1970). Fifteen milliliters of $0.01 \mathrm{~mol} \mathrm{l}^{-1} \mathrm{HCl}$ solution was added to $50-\mathrm{ml}$ filtered seawater samples, and the $A_{\mathrm{T}}$ of the samples was then estimated from the $\mathrm{pH}$ values of the acidified sample. Sample temperature was kept constant at $25.0^{\circ} \mathrm{C}$ (=298.15 K) during $\mathrm{pH}$ and $A_{\mathrm{T}}$ measurements by using a water bath. The standard deviation $(1 \sigma)$ of the $A_{\mathrm{T}}$ values obtained by this method by the previous authors was $4 \mu \mathrm{mol} \mathrm{kg}{ }^{-1}$ (Suzuki and Kawahata 1999). $F_{\mathrm{P}}$ was measured with an MDS MkV/L photon sensor (Alec Electronics Co Ltd, Japan) at the observation site. The salinity of the seawater was obtained using an electrode conductivity salinometer MODEL 601 MK-IV (Yeo-Kal Electronics Pty Ltd, Australia).

Experiments to measure $P_{\mathrm{n}}$ and $G$ in the coral community during summer were carried out over $24 \mathrm{~h}$ from 0900 hours on 26 August to 0900 hours on 27 August 2004. Seawater samples $(500 \mathrm{ml})$ were collected immediately before and after the experiment to determine the longterm salinity trend. The net photosynthesis and calcification rates $\left(P_{\mathrm{n}}\right.$ and $\left.G\right)$ of the communities in the aquarium were determined in this study by using the following procedure every $3 \mathrm{~h}$ over $24 \mathrm{~h}$ : (1) sampling of seawater in the aquarium in a cylindrical bottle, (2) isolation of the seawater in the aquarium from surrounding waters, (3) measurement of $\mathrm{pH}$ and $A_{\mathrm{T}}$ of samples, (4) resampling of the 


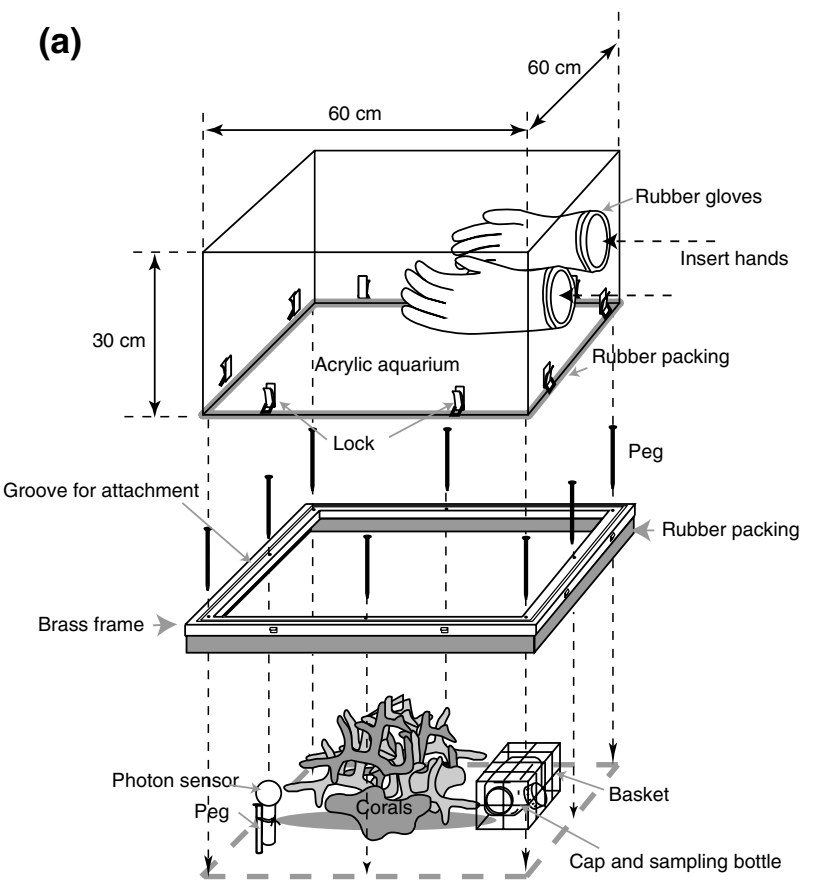

(b)

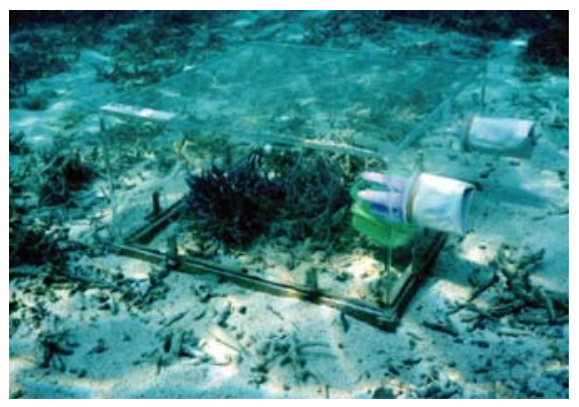

Fig. 3 Aquarium used for in situ incubation in this study. a Schematic diagram of aquarium and other equipment, b photograph of closed aquarium on site

seawater in the aquarium after $3 \mathrm{~h}$, and (5) exchange of water in the aquarium with surrounding water. These steps were repeated every $3 \mathrm{~h}$ over 1 day $(24 \mathrm{~h})$. The interval of $3 \mathrm{~h}$ was chosen to minimize damage to the coral community during sealing of the aquarium, and to obtain adequate temporal sampling of the seawater chemistry. The $\mathrm{pH}$ and $A_{\mathrm{T}}$ values of samples were measured within $1 \mathrm{~h}$ of sampling in a laboratory at Shiraho Village. The photon flux sensor was placed inside the aquarium (Fig. 3) to measure natural $F_{\mathrm{P}}$ at 1-min intervals during the experiment.

Determination of $P_{\mathrm{n}}$ and $G$

Values of $P_{\mathrm{n}}$ and $G$ were determined using the alkalinity anomaly method of Smith and Key (1975) and Smith and Kinsey (1978). Chisholm and Gattuso (1991) compared $G$ measured by this method with values obtained by complexometric titration of $\mathrm{Ca}$ with EGTA and concluded that
Table 1 Definitions of symbols

\begin{tabular}{|c|c|}
\hline Symbol & Parameter \\
\hline$A_{\mathrm{T}}$ & Total alkalinity \\
\hline$C_{\mathrm{T}}$ & Total carbon dioxide \\
\hline$A_{\mathrm{T} 0}$ & Initial total alkalinity \\
\hline$C_{\mathrm{T} 0}$ & Initial total carbon dioxide \\
\hline$B_{\mathrm{T}}$ & Total boron \\
\hline$K_{1}^{\prime}$ & First dissociation constant of carbonic acid \\
\hline$K_{2}^{\prime}$ & Second dissociation constant of carbonic acid \\
\hline$K_{\mathrm{B}}{ }^{\prime}$ & Dissociation constant of boric acid \\
\hline$\rho_{\mathrm{W}}$ & Density of seawater \\
\hline$\rho_{\mathrm{R}}$ & Density of reef rock \\
\hline$P_{\mathrm{n}}$ & Net photosynthesis rate \\
\hline$P_{\mathrm{g}}$ & Gross photosynthesis rate \\
\hline$R$ & Respiration rate \\
\hline$G$ & Calcification rate \\
\hline$G^{\prime}$ & Generalized calcification rate \\
\hline$k_{P}$ & Constant, defined in Eq. (9) \\
\hline$k_{G}$ & Constant, defined in Eq. (12) \\
\hline$k$ & $=k_{P} \cdot k_{G}$, constant, defined in Eq. (14) \\
\hline$k^{\prime}$ & $=k / 20.7$, constant, defined in Eq. $(15)$ \\
\hline Cov & Coverage of corals \\
\hline$F_{\mathrm{P}}$ & Photon flux density \\
\hline$F_{\mathrm{P} 0}$ & Photon flux density on sea surface \\
\hline$h$ & Water depth \\
\hline$\alpha$ & Albedo of sea surface \\
\hline$a$ & Constant, defined in Eq. (19) \\
\hline$b$ & Constant, defined in Eq. (19) \\
\hline$c$ & Constant, defined in Eq. (19) \\
\hline$\lambda$ & Extinction coefficient of seawater \\
\hline$V_{\mathrm{R}}$ & Growth rate of the reefs \\
\hline$V_{\mathrm{S}}$ & Rate of sea-level rise \\
\hline$D$ & Diffusion coefficient in Eq. (21) \\
\hline M & Molecular mass of $\mathrm{CaCO}_{3}$ \\
\hline$x$ & Coordinates on horizontal axes \\
\hline$y$ & Coordinates on vertical axes \\
\hline$K_{x}$ & Horizontal eddy diffusion coefficient \\
\hline$K_{v}$ & Vertical eddy diffusion coefficient \\
\hline
\end{tabular}

the alkalinity anomaly method is valid, especially for measuring $G$. In this method, $P_{\mathrm{n}}$ and $G$ values are obtained by solving simultaneous equations relating to a conservation law of $A_{\mathrm{T}}$ and total carbon dioxide $\left(C_{\mathrm{T}}\right) . C_{\mathrm{T}}$ is defined as the sum of concentrations of three carbonate species $\left(C_{\mathrm{T}}=\left[\mathrm{CO}_{2}(\mathrm{aq})^{*}\right]+\left[\mathrm{HCO}_{3}^{-}\right]+\left[\mathrm{CO}_{3}^{2-}\right]\right.$, where $\mathrm{CO}_{2}(\mathrm{aq})^{*}$ is dissolved carbon dioxide). These concentrations and $C_{\mathrm{T}}$ were calculated from equilibrium equations for $\mathrm{pH}$ and $A_{\mathrm{T}}$ proposed by Suzuki et al. (1995). The thermodynamic parameters of the first and second dissociation constants of carbonic acid $\left(K_{1}{ }^{\prime}\right.$ and $\left.K_{2}{ }^{\prime}\right)$ (Mehrbach et al. 1973), the 
(a)

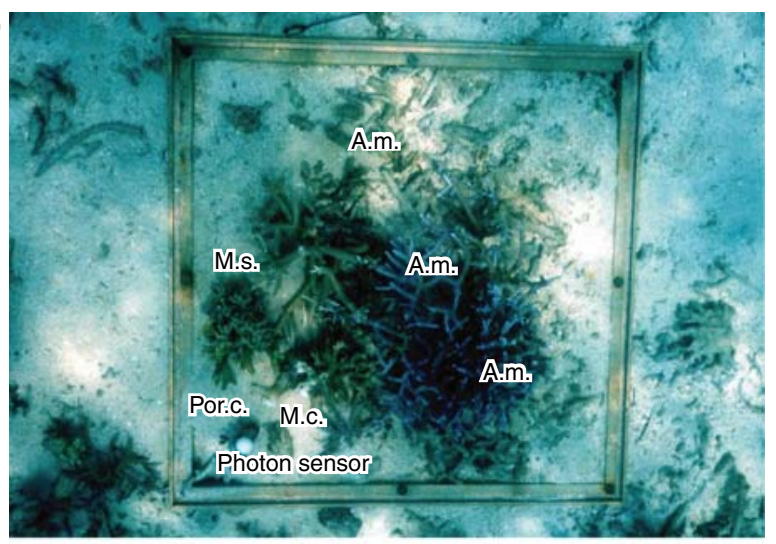

(b)

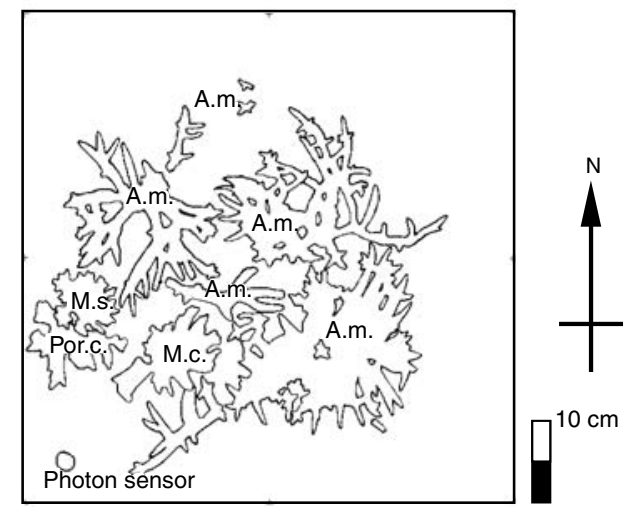

M.c. Montipora cactus A.m. Acropora microphthalma M.s. Montipora stellata Por.c. Porites cylindrica

Fig. 4 Makeup of the coral community in the aquarium. a Underwater photograph, b sketch

dissociation constant of boric acid $\left(K_{\mathrm{B}}{ }^{\prime}\right)$ (Lyman 1957), total borate concentration $\left(B_{\mathrm{T}}\right)$ (Culkin 1965), and the dissociation constant for water $\left(K_{\mathrm{W}}\right)$ and activity coefficient of hydrogen ions $\left(f_{\mathrm{H}}\right)$ of Culberson and Pytkowicz (1973) were adopted in this study. These constants were converted to the appropriate values considering the sample temperature $(T=298.15 \mathrm{~K})$ and measured salinity. The $G$ and $P_{\mathrm{n}}$ values ( $\mu \mathrm{mol} \mathrm{m} \mathrm{m}^{-2}$ per unit time) for the community are given by:

$G=-\frac{1}{2} \rho_{\mathrm{W}} H \Delta A_{\mathrm{T}} / \Delta t$,

and

$P_{\mathrm{n}}=-\rho_{\mathrm{W}} H \Delta C_{\mathrm{T}} / \Delta t-G$,

where $\rho_{\mathrm{W}}$ is density of seawater, $H$ is height of the aquarium $(H=0.3 \mathrm{~m}), \Delta A_{\mathrm{T}} / \Delta t$ is the change in $A_{\mathrm{T}}$ in $\mu \mathrm{mol} \mathrm{kg}{ }^{-1}$ per unit time, and $\Delta C_{\mathrm{T}} / \Delta t$ is the change in $C_{\mathrm{T}}$ in $\mu \mathrm{mol} \mathrm{kg}{ }^{-1}$ per unit time.
Table 2 Coverage of coral species in the aquarium

\begin{tabular}{lc}
\hline Species & $\begin{array}{l}\text { Coverage } \\
(\%)\end{array}$ \\
\hline Montipora stellata & 1.9 \\
Montipora cactus & 1.1 \\
Acropora & 16.6 \\
$\quad$ microphthalma & \\
Porites cylindrica & 1.2 \\
Total & 20.7 \\
\hline
\end{tabular}

\section{Results}

Coverage and species composition

Total coverage of the hermatypic coral community in the aquarium was $20.7 \%$. A. microphthalma $(16.6 \%)$ was the species with the highest coverage. Montipora cactus (1.9\%), Porites cylindrica (1.2\%), and Montipora stellata (1.1\%) were also present (Fig. 4, Table 2). This combination of coral species is representative of a typical branching Acropora community on the inner reef flat (Fig. 2).

Results of incubation experiments

Changes in $\mathrm{pH}, A_{\mathrm{T}}$, and $C_{\mathrm{T}}$ inside the aquarium before and after sealing at 3-h intervals are shown in Fig. 5 and Table 3. Three-hour averages of $F_{\mathrm{P}}, G, P_{\mathrm{n}}$, and concentrations of carbon species $\left(\left[\mathrm{CO}_{2}(\mathrm{aq})^{*}\right]\right.$ and $\left.\left[\mathrm{CO}_{3}^{2-}\right]\right)$ are shown in Fig. 6 and Table 3. The $F_{\mathrm{P}}$ values obtained over the period
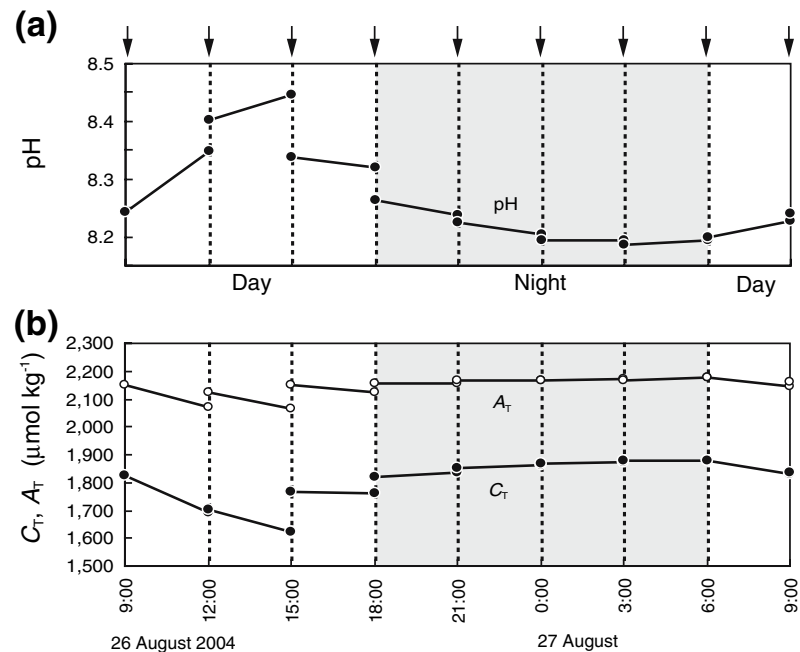

Fig. 5 Time series of a $\mathrm{pH}$, b total alkalinity $\left(A_{\mathrm{T}}\right)$, and computed total carbon $\left(C_{\mathrm{T}}\right)$, assuming equilibrium of seawater. Arrows indicate seawater-sampling times 
Table 3 Variations in $\mathrm{pH}$, total alkalinity $\left(A_{\mathrm{T}}\right)$, and total carbon $\left(C_{\mathrm{T}}\right)$ every $3 \mathrm{~h}$, and average rates of photon flux density $\left(F_{\mathrm{P}}\right)$, calcification rate $(G)$, net photosynthesis rate $\left(P_{\mathrm{n}}\right)$, $\left[\mathrm{CO}_{2}(\mathrm{aq})^{*}\right]$, and $\left[\mathrm{CO}_{3}^{2-}\right]$

\begin{tabular}{|c|c|c|c|c|c|c|c|c|}
\hline & $\mathrm{pH}$ (NBS) & $\begin{array}{l}A_{\mathrm{T}} \\
(\mu \mathrm{mol} \\
\left.\mathrm{kg}^{-1}\right)\end{array}$ & $\begin{array}{l}C_{\mathrm{T}} \\
(\mu \mathrm{mol} \\
\left.\mathrm{kg}^{-1}\right)\end{array}$ & $\begin{array}{l}F_{\mathrm{P}} \\
(\mathrm{mol} \\
\left.\mathrm{m}^{-2} \mathrm{~h}^{-1}\right)\end{array}$ & $\begin{array}{l}G \\
(\mu \mathrm{mol} \\
\left.\mathrm{m}^{-2} \mathrm{~h}^{-1}\right)\end{array}$ & $\begin{array}{l}P_{\mathrm{n}} \\
(\mu \mathrm{mol} \\
\left.\mathrm{m}^{-2} \mathrm{~h}^{-1}\right)\end{array}$ & $\begin{array}{l}{\left[\mathrm{CO}_{2}(\mathrm{aq})^{*}\right]} \\
(\mu \mathrm{mol} \\
\left.\mathrm{kg}^{-1}\right)\end{array}$ & $\begin{array}{l}{\left[\mathrm{CO}_{3}^{2-}\right]} \\
(\mu \mathrm{mol} \\
\left.\mathrm{kg}^{-1}\right)\end{array}$ \\
\hline \multicolumn{9}{|c|}{$2004 / 8 / 26$} \\
\hline $9: 00^{\mathrm{a}}$ & 8.243 & 2149 & 1827 & 4.11 & 4169 & 9910 & 7.852 & 228.91 \\
\hline $12: 00^{\mathrm{b}}$ & 8.348 & 2068 & 1690 & & & & & \\
\hline $12: 00^{\mathrm{a}}$ & 8.403 & 2122 & 1700 & 4.17 & 2863 & 5071 & 5.225 & 278.64 \\
\hline $15: 00^{b}$ & 8.446 & 2066 & 1623 & & & & & \\
\hline $15: 00^{\mathrm{a}}$ & 8.339 & 2148 & 1765 & 1.69 & 1124 & -400 & 7.105 & 245.41 \\
\hline $18: 00^{b}$ & 8.320 & 2126 & 1758 & & & & & \\
\hline $18: 00^{\mathrm{a}}$ & 8.262 & 2155 & 1820 & 0.06 & 0 & -1546 & 9.072 & 216.68 \\
\hline $21: 00^{b}$ & 8.237 & 2155 & 1836 & & & & & \\
\hline \multicolumn{9}{|c|}{ 2004/8/27 } \\
\hline $21: 00^{a}$ & 8.225 & 2165 & 1852 & 0.00 & 0 & -1258 & 10.083 & 205.02 \\
\hline $0: 00^{\mathrm{b}}$ & 8.204 & 2165 & 1865 & & & & & \\
\hline $0: 00^{\mathrm{a}}$ & 8.193 & 2164 & 1869 & 0.00 & -270 & -221 & 10.720 & 197.48 \\
\hline $3: 00^{\mathrm{b}}$ & 8.193 & 2169 & 1874 & & & & & \\
\hline $3: 00^{\mathrm{a}}$ & 8.187 & 2167 & 1876 & 0.00 & -358 & 174 & 10.804 & 197.20 \\
\hline $6: 00^{b}$ & 8.195 & 2174 & 1878 & & & & & \\
\hline $6: 00^{\mathrm{a}}$ & 8.198 & 2179 & 1881 & 0.95 & 1815 & 3144 & 10.143 & 203.72 \\
\hline $9: 00^{\mathrm{b}}$ & 8.226 & 2144 & 1832 & & & & & \\
\hline
\end{tabular}
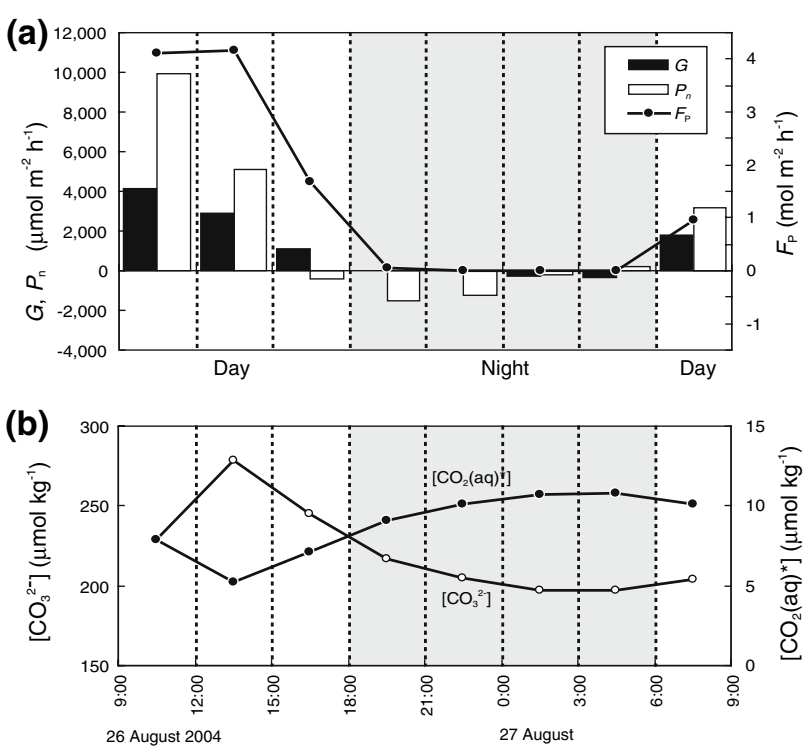

Fig. 6 Time series of a photon flux density $\left(F_{\mathrm{P}}\right)$, calcification rate $(G)$, and net photosynthesis rate $\left(P_{\mathrm{n}}\right)$, and $\mathbf{b}$ calculated concentrations of carbonic species

from 0900 to 1500 hours on 26 August were high (about $4 \mathrm{~mol} \mathrm{~m}^{-2} \mathrm{~h}^{-1}$ ) and remained relatively high during the day. $F_{\mathrm{P}}$ decreased during the evening, and was almost $0 \mathrm{~mol} \mathrm{~m} \mathrm{~m}^{-2}$ through the night. It increased again at sunrise, indicating a typical diurnal variation. The $P_{\mathrm{n}}$ value was highest $\left(9,910 \mu \mathrm{mol} \mathrm{m} \mathrm{m}^{-2} \mathrm{~h}^{-1}\right)$ between 0900 and 1200 hours on 26 August, and then gradually decreased.
It was negative during the night, reaching a minimum $\left(-1,546 \mu \mathrm{mol} \mathrm{m}{ }^{-2} \mathrm{~h}^{-1}\right)$ between 1800 and 2100 hours. It returned to a positive value around sunrise, when $F_{\mathrm{P}}$ also increased. The variation of $G$ was similar to that of $P_{\mathrm{n}}$. Maximum $G\left(4,169 \mu \mathrm{mol} \mathrm{m}{ }^{-2} \mathrm{~h}^{-1}\right)$ was observed between 0900 and 1200 hours, but it was low at almost $0 \mu \mathrm{mol}$ $\mathrm{m}^{-2} \mathrm{~h}^{-1}$ during the night. $\left[\mathrm{CO}_{2}(\mathrm{aq})^{*}\right]$ decreased from 0900 to 1500 hours, and rose slowly during the afternoon and night. A small decrease was observed early in the morning of 27 August. The temporal change of $\left[\mathrm{CO}_{3}^{2-}\right]$ showed an inverse relationship with that of $\left[\mathrm{CO}_{2}(\mathrm{aq})^{*}\right]$.

\section{Discussion}

Models of photosynthesis and calcification

$P_{n}$ model

The trend of the temporal change of $P_{\mathrm{n}}$ was very similar to that of $F_{\mathrm{P}}$ (coefficient of determination $r^{2}=0.75$ ) (Fig. 6). $P_{\mathrm{n}}$ is the difference between respiration rate $(R)$ and gross photosynthesis $\left(P_{\mathrm{g}}\right)$ :

$P_{\mathrm{n}}=P_{\mathrm{g}}-R$.

Therefore, $P_{\mathrm{n}}\left(\right.$ or $P_{\mathrm{g}}$ ) is clearly dependent on $F_{\mathrm{P}}$. This relationship has been well documented in studies of the production of coral colonies (Chalker 1981), reefs (Barnes 
and Devereux 1984), and other photosynthetic organisms (Zimmerman et al. 1997; Martin et al. 2006).

Acceleration of coral growth and photosynthesis rates because of increased levels of $\left[\mathrm{CO}_{2}(\mathrm{aq})^{*}\right]$ have been reported from experiments on diatoms (Riebesell et al. 1993), green algae Halimeda (Borowitzka and Larkum 1976), giant algal coenocytes (Lucas 1975), red algae (Borowitzka 1981), red calcareous algae (Gao et al. 1993), and sea grasses (Zimmerman et al. 1997). The $P_{\mathrm{n}}$ value recorded between 1200 and 1500 hours on 26 August was much lower than that recorded between 0900 and 1200 hours on the same day, although $F_{\mathrm{P}}$ values over the two periods were almost the same. It is interesting that a decrease in $\left[\mathrm{CO}_{2}(\mathrm{aq})^{*}\right]$ was observed over that time. The $P_{\mathrm{n}}$ value between 1500 and 1800 hours on 26 August was also lower than that between 0600 and 0900 hours on 27 August, whereas $F_{\mathrm{P}}$ during the former period was higher than that during the latter period. $\left[\mathrm{CO}_{2}(\mathrm{aq})^{*}\right]$ between 1500 and 1800 hours on 26 August was less than that between 0600 and 0900 hours on 27 August. These results strongly suggest that the $P_{\mathrm{g}}$ rate is dependent on $\left[\mathrm{CO}_{2}(\mathrm{aq})^{*}\right]$.

It is here assumed that $P_{\mathrm{g}}$ is proportional to both $F_{\mathrm{P}}$ and $\left[\mathrm{CO}_{2}(\mathrm{aq})^{*}\right]$, because, as discussed above, it depends on both:

$P_{\mathrm{g}}=k_{P} \cdot F_{\mathrm{P}} \cdot\left[\mathrm{CO}_{2}(\mathrm{aq})^{*}\right]$

where $k_{P}$ is a constant. The $P_{\mathrm{g}}-F_{\mathrm{P}}$ curve is usually composed of two phases: a linear phase at low $F_{\mathrm{P}}$; and a constant phase, owing to saturation, at higher $F_{\mathrm{P}}$. In previous studies, $P_{\mathrm{g}}$ was commonly fitted to the non-linear part of the function (Chalker 1981; Barnes and Devereux 1984; Zimmerman et al. 1997). The $P_{\mathrm{g}}$ in this study was, however, assumed to be a linear function of $F_{\mathrm{P}}$, because the saturation levels were not observed in this study. Here, $P_{\mathrm{n}}$ is derived by substituting $P_{\mathrm{g}}$ from Eq. (8) in Eq. (7) on the assumption that $R$ is constant. Thus,

$P_{\mathrm{n}}=k_{P} \cdot F_{\mathrm{P}} \cdot\left[\mathrm{CO}_{2}(\mathrm{aq})^{*}\right]-R$.

Using the least-squares method (Fig. 7), the two unknowns, $k_{P}$ and $R$, were determined as follows:

$k_{P}=3.054 \times 10^{-4}$

and

$R=1,058 \mu \mathrm{mol} \mathrm{m}{ }^{-2} \mathrm{~h}^{-1}\left(=25,392 \mu \mathrm{mol} \mathrm{m}^{-2} \mathrm{~d}^{-1}\right)$.

Units used for $P_{\mathrm{n}}, F_{\mathrm{P}}$, and $\left[\mathrm{CO}_{2}(\mathrm{aq})^{*}\right]$ in this model were $\mu \mathrm{mol} \mathrm{m}{ }^{-2} \mathrm{~h}^{-1}, \mathrm{~mol} \mathrm{~m}{ }^{-2} \mathrm{~h}^{-1}$, and $\mu \mathrm{mol} \mathrm{kg}{ }^{-1}$, respectively. The coefficient of determination for the data of this study

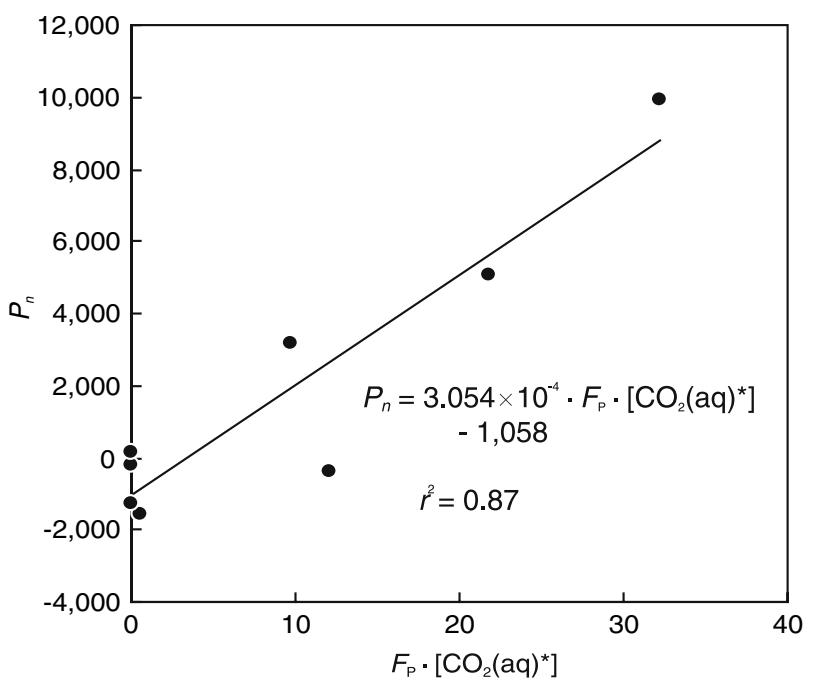

Fig. 7 Regression of net photosynthesis rate $\left(P_{\mathrm{n}}\right)$ with product of photon flux density $\left(F_{\mathrm{P}}\right)$ and $\left[\mathrm{CO}_{2}(\mathrm{aq})^{*}\right]$

as described by Eq. (9) $\left(r^{2}=0.87\right)$ (Fig. 7) suggests that this model for $P_{\mathrm{n}}$ is valid.

\section{$G$ model}

Because the temporal behavior patterns of $G$ are similar to those of $P_{\mathrm{n}}\left(=P_{\mathrm{g}}-R\right.$ ) (Fig. 6), $G$ and $P_{\mathrm{g}}$ should be expressed by similar equations. There is good correlation between $G$ and $P_{\mathrm{g}}\left(r^{2}=0.89\right)$. A similar positive correlation between $G$ and $P_{\mathrm{n}}$ (or $P_{\mathrm{g}}$ ) for hermatypic corals has been reported by Suzuki et al. (1995), Gattuso et al. (1999), and Barnes and Devereux (1984), and termed "light enhanced calcification" (Goreau 1959; Goreau and Goreau 1959; Barnes and Chalker 1990; Gattuso et al. 1999, 2000). A model where $G$ is a function of $P_{\mathrm{g}}$ is therefore adopted in this study.

The $G$ is a function of $\Omega_{\mathrm{arag}}$ on the basis of coral incubation experiments. Values of $G$ have previously been fitted to a non-linear $\Omega_{\text {arag }}$ function of the saturation curve for the hermatypic coral Stylophora pistillata (Gattuso et al. 1998a), to linear functions of $\Omega_{\text {arag }}$ for both the hermatypic coral Porites porites (Marubini and Thake 1999 ) and a coral reef community (Odhe and van Woesik 1999; Leclercq et al. 2000, 2002). Langdon et al. (2000) found a similar linear relationship between $G$ and $\Omega_{\text {arag }}$ for a coral reef community during short-term (days) and longterm (months to years) experiments carried out in the Biosphere 2 ocean.

Although $\Omega_{\text {arag }}$ is proportional to the product of $\left[\mathrm{Ca}^{2+}\right]$ and $\left[\mathrm{CO}_{3}^{2-}\right]$, it is here expressed as a function only of $\left[\mathrm{CO}_{3}^{2-}\right]$, because the concentration of $\mathrm{Ca}^{2+}$ in the seawater was so high $\left(\sim 10^{4} \mu \mathrm{mol} \mathrm{kg}{ }^{-1}\right)$ that small changes in its 


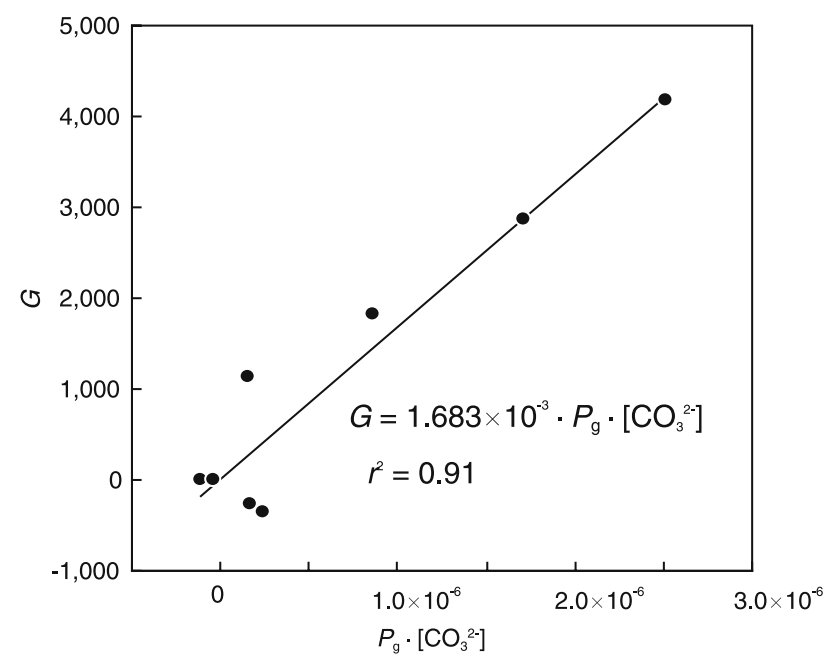

Fig. 8 Regression of calcification rate $(G)$ with product of gross photosynthesis rate $\left(P_{\mathrm{g}}\right)$ and $\left[\mathrm{CO}_{3}^{2-}\right]$

concentration had negligible effect on $\Omega_{\text {arag. }}$. Thus, it was assumed that $G$ is proportional to the product of $P_{\mathrm{g}}$ and $\left[\mathrm{CO}_{3}^{2-}\right]$ :

$G=k_{G} \cdot P_{\mathrm{g}} \cdot\left[\mathrm{CO}_{3}^{2-}\right]$,

where $k_{G}$ is a constant. The value of the coefficient $k_{G}$ was determined by using the least-squares method:

$k_{G}=1.683 \times 10^{-3}$.

The units for $G, P_{\mathrm{g}}$, and $\left[\mathrm{CO}_{3}^{2-}\right]$ are $\mu \mathrm{mol} \mathrm{m}{ }^{-2} \mathrm{~h}^{-1}$, $\mu \mathrm{mol} \mathrm{m} \mathrm{m}^{-2} \mathrm{~h}^{-1}$, and $\mu \mathrm{mol} \mathrm{kg}{ }^{-1}$, respectively. The regression line (Fig. 8) derived from Eq. (12) suggests that the relationship expressed by Eq. (12) is valid $\left(r^{2}=0.91\right)$.

The Eq. (12) model for $G$ includes the metabolic parameter $P_{\mathrm{g}}$, which can be removed by substitution of Eq. (8) in Eq. (12). Thus:

$G=k \cdot F_{\mathrm{P}} \cdot\left[\mathrm{CO}_{2}(\mathrm{aq}) *\right] \cdot\left[\mathrm{CO}_{3}^{2-}\right]$,

where $k=k_{P} \cdot k_{G}$, and $G$ is now expressed only in terms of physical and chemical parameters.

Model for coral reef formation

\section{Calcification rate}

The values of $G$ given by Eq. (14) can be applied only to the calcification rate of the coral community in the aquarium, because the biomass within the community varies from place to place. Another equation must be developed that can be applied more generally. The calcification rate of coral communities may depend on the biomass per unit area, i.e., map view coverage. Therefore, the simple model that the calcification rate is proportional to coverage $(\mathrm{Cov}, \%)$ is here proposed. The revised calcification rate $\left(G^{\prime}\right)$ is a product of $G$ and Cov:

$$
\begin{aligned}
G^{\prime} & =G \cdot \mathrm{Cov} / 20.7 \\
& =k^{\prime} \cdot F_{\mathrm{P}} \cdot\left[\mathrm{CO}_{2}(\mathrm{aq}) *\right] \cdot\left[\mathrm{CO}_{3}^{2-}\right] \cdot \mathrm{Cov},
\end{aligned}
$$

where $k^{\prime}=k / 20.7$. The value of 20.7 in Eq. (15) is the actual coverage (\%) obtained for the community in this study.

The $F_{\mathrm{P}}$ received by corals (Eq. 15) can be calculated only as a function of water depth $(h)$. It decreases exponentially with increasing depth as follows:

$F_{\mathrm{P}}=F_{\mathrm{P} 0}(1-\alpha) \exp [-\lambda h]$,

where $F_{\mathrm{P} 0}$ is the photon flux density at the sea surface, $\alpha$ is the albedo of seawater, and $\lambda$ is the absorption coefficient of seawater.

The $\left[\mathrm{CO}_{2}(\mathrm{aq})^{*}\right]$ and $\left[\mathrm{CO}_{3}^{2-}\right]$ in Eq. (15) can be computed from $C_{\mathrm{T}}$, if some assumptions are made. Most decreases in $C_{\mathrm{T}}$ are derived from calcification, because heterotrophic organisms living around the corals consume most of the organic matter, and because the $P_{\mathrm{g}} / R$ ratio of the coral community is close to 1 (Odum and Odum 1955; Kinsey 1977; Crossland et al. 1991; Nakamori et al. 1992; Gattuso et al. 1998b). So, it is assumed that all of the $C_{\mathrm{T}}$ change is the result of calcification. The value of $A_{\mathrm{T}}$ is given by the following equation:

$A_{\mathrm{T}}=A_{\mathrm{T} 0}-2\left(C_{\mathrm{T} 0}-C_{\mathrm{T}}\right)$,

where $A_{\mathrm{T} 0}$ and $C_{\mathrm{T} 0}$ are initial values of $A_{\mathrm{T}}$ and $C_{\mathrm{T}}$, respectively. Using $C_{\mathrm{T}}$ and $A_{\mathrm{T}}$ computed from Eq. (17), $\left[\mathrm{CO}_{2}(\mathrm{aq})^{*}\right]$ and $\left[\mathrm{CO}_{3}^{2-}\right]$ can be computed by solving the equations in equilibrium (Suzuki et al. 1995).

Modeling of Cov in Eq. (15) is difficult, because Cov is affected by damage from various sources, e.g., by bottom sedimentation, turbidity, and nutrients. However, coral coverage was observed to be lower in depressions than in other parts of the study area. A simple assumption that the coverage is $0 \%$ where the reef surface is depressed and $100 \%$ in other areas was introduced. This concept is expressed by the following conditions of depth $(h)$ :

$\operatorname{Cov} \rightarrow\left\{\begin{array}{l}0 \%, \quad \text { if } \nabla h \approx 0 \cap \nabla^{2} h<0 \\ 100 \%, \text { otherwise }\end{array}\right.$,

where $\nabla h$ is the gradient of $h$, and $\nabla^{2} h$ is curvature of $h$. The surface is flat when $\nabla h$ equals 0 ; it is depressed if $\nabla^{2} h<0$. A simple function to describe coverage was defined as follows: 
$\operatorname{Cov}=50\left\{1+\tanh \left[a \nabla^{2} h+b(\nabla h)^{2}-c\right]\right\}$,

where $a, b$, and $c$ are constants. Furthermore, corals tend not to inhabit an environment shallower than the low-tide level, so the following condition was applied:

$\operatorname{Cov}=0 \%, \quad$ if $h<0.6 \mathrm{~m}$.

Thus, Cov is a function of $h$ in this model.

In conclusion, $G^{\prime}$ as given by Eq. (15) can be written as a simple function of two variables, i.e., $h$ and $C_{\mathrm{T}}$.

\section{Reef profile}

Depth $(h)$ is considered to influence various phenomena in a reef environment; for example, reef growth, sea-level change, and mass movement by erosion or deposition. Changes in $h$ can be expressed by the following equation:

$\frac{\partial h}{\partial t}=-V_{\mathrm{R}}+V_{\mathrm{S}}+D \frac{\partial^{2} h}{\partial x^{2}}$,

where $x$ is a coordinate on the horizontal axis, $V_{\mathrm{R}}$ is the growth rate of the reef, $V_{\mathrm{S}}$ is the rate of sea-level rise, and $D$ is a constant. The first term of right-hand side represents a decrease in $h$ as a result of upward reef growth. The second term represents an increase in $h$ as a result of sealevel rise. The last term has the effect of surface smoothing, and represents transportation of carbonate mass by erosion and secondary deposition. This term was proposed by Scheidegger (1970) by drawing an analogy between geomorphology and thermodynamics. The $V_{\mathrm{R}}$ of Eq. (21) can be derived from the variable $G^{\prime}$ by using the following equation:

$V_{\mathrm{R}}=\frac{M}{\rho_{\mathrm{R}}} G^{\prime}$

where $M$ is molecular mass of $\mathrm{CaCO}_{3}$ and $\rho_{\mathrm{R}}$ is the density of the reef rock. Buddemeier and Smith (1988) concluded that the average value of $\rho_{\mathrm{R}}$ within reef systems is $1.4 \mathrm{~g} \mathrm{~cm}^{-3}$.

\section{Distribution of $C_{T}$}

The distribution of $C_{\mathrm{T}}$ in seawater in a reef environment may exhibit a complicated pattern, caused mainly by tidal effects. Total fluxes due to ebb and flow are the same. It implies that the averaged advection should be zero. If considered over long periods (years), and at large scale (meters to kilometers), the tidal effects can be represented by a simple eddy, and approximated by eddy diffusion. The $C_{\mathrm{T}}$ distribution can then be determined using the following two-dimensional diffusion equation:

$\frac{\partial C_{\mathrm{T}}}{\partial t}=K_{x} \frac{\partial C_{\mathrm{T}}}{\partial x^{2}}+K_{y} \frac{\partial C_{\mathrm{T}}}{\partial y^{2}}$,

where $x$ and $y$ are coordinates on horizontal and vertical axes, and $K_{x}$ and $K_{y}$ are the horizontal and vertical eddy diffusion coefficients of seawater, respectively. The boundary condition between seawater and coral reef $(y=h)$ is given by Fick's law of diffusion:

$G^{\prime}=-\left.\rho_{\mathrm{W}} K_{y} \frac{\partial C_{\mathrm{T}}}{\partial y}\right|_{y=h}$,

where $G^{\prime}$ is the $C_{\mathrm{T}}$ flux as a result of calcification.

\section{Simulations of coral reef formation}

Computer simulations were carried out by applying the finite difference method on variables indicating space and time to the geochemical model for coral reef formation described above. Depth profiles given by Eq. (21) were calculated every $20 \mathrm{~m}$ along the $x$-axis $(0 \leq x \leq 2,560 \mathrm{~m})$. The initial profile of $h$ is represented by an inclined flat plane (Fig. 9a). The boundary conditions at $x=0$ and $x=2,560$ were chosen to satisfy $\partial h / \partial t=V_{\mathrm{S}}$. The rate of sea-level rise, $V_{\mathrm{S}}$ in Eq. (21) and in boundary conditions, was constant at $0.002 \mathrm{~m} \mathrm{year}^{-1}$. The calculations of $C_{\mathrm{T}}$ distribution from Eq. (23) were carried out in two-dimensional space $(2,560 \times 16 \mathrm{~m})$. Grid dimensions of $20 \mathrm{~m}$ horizontal $(x)$ and $0.5 \mathrm{~m}$ vertical $(y)$ were chosen to provide adequate resolution of a vertical cross-section of reef topography. The reef-seawater boundary was mapped onto the lattice shown in Fig. 10 and was updated for every output of topography in the simulation. The initial condition for $C_{\mathrm{T}}$ of seawater was set at a homogeneous concentration of $2,000 \mu \mathrm{mol} \mathrm{kg} \mathrm{kg}^{-1}$ (Fig. 9b). Zero flux boundary conditions were applied at the atmosphereseawater and reef-seawater interfaces in the horizontal
Fig. 9 Initial conditions of a water depth profile and b concentration of total carbon dioxide

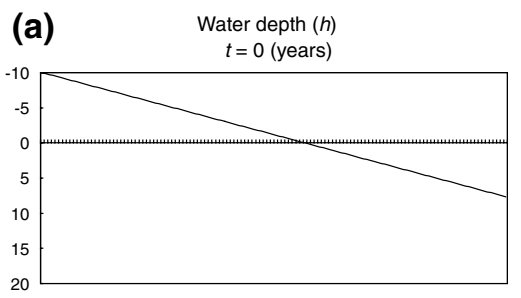

(b) Concentrations of total carbon dioxicide $\left(C_{T}\right)$

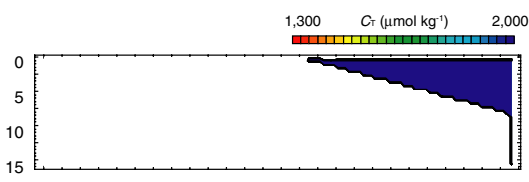


Fig. 10 Modeled reef-seawater boundary and boundary conditions

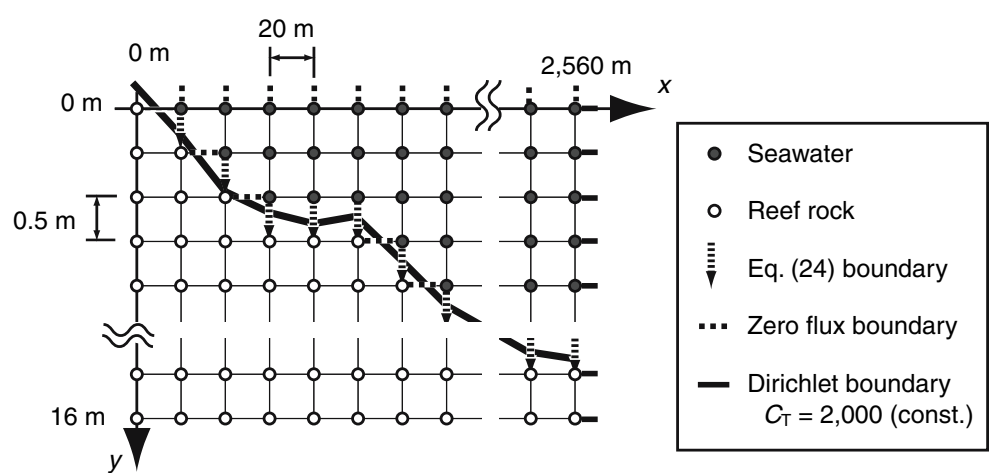

Table 4 Parameters used for computer simulations

\begin{tabular}{lll}
\hline Symbol & Value & Unit \\
\hline$A_{\mathrm{T} 0}$ & 2400 & $\mu \mathrm{mol} \mathrm{kg}^{-1}$ \\
$C_{\mathrm{T} 0}$ & 2000 & $\mu \mathrm{mol} \mathrm{kg}^{-1}$ \\
$B_{\mathrm{T}}$ & 430 & $\mu \mathrm{mol} \mathrm{kg}^{-1}$ \\
$K_{1}$, & $9.95 \times 10^{-7}$ & \\
$K_{2}$, & $7.61 \times 10^{-10}$ & \\
$K_{\mathrm{B}}$, & $2.03 \times 10^{-9}$ & \\
$F_{\mathrm{P} 0}$ & $2.50 \times 10^{10}$ & \\
$\alpha$ & 0.07 & \\
$a$ & 5.0 & \\
$b$ & 50 & \\
$c$ & 0.2 & \\
$\lambda$ & 0.44 & $\mathrm{~m}^{2}$ year $^{-1}$ \\
$D$ & 1.0 & $\mathrm{~m}^{2}$ year $^{-1}$ \\
$K_{x}$ & $10^{7} \sim 10^{8}$ & $\mathrm{~m}^{2}$ year $^{-1}$ \\
$K_{v}$ & $1.0 \times 10^{4}$ & \\
\hline
\end{tabular}

direction. The vertical component of the flux at the reefseawater boundary was determined from Eq. (24). The Dirichlet condition $\left(C_{\mathrm{T}}=2,000 \mu \mathrm{mol} \mathrm{kg}{ }^{-1}\right)$ was employed at the boundary $2,560 \mathrm{~m}$ distant from the shore, because $C_{\mathrm{T}}$ in the offshore environment was assumed to be constant at around $2,000 \mu \mathrm{mol} \mathrm{kg}{ }^{-1}$ (Fig. 9). The period of the simulation step was set to $1.0 \times 10^{-6}$ years for the past 5,000 years. The values of other parameters used in the simulation are provided in Table 4.

First, the effects of changing the eddy diffusion coefficient, $K_{x}$, were examined. The topography at $t=$ 5,000 years for the four cases of $K_{x}=1.0 \times 10^{7}, 2.5 \times 10^{7}$, $5.0 \times 10^{7}$, and $1.0 \times 10^{8} \mathrm{~m}^{2}$ year $^{-1}$ were calculated (Fig. 11). The crest-like structure emerged for each of these simulations. The rate of reef deposition was higher when $K_{x}$ was higher. The gradient of the simulated $C_{\mathrm{T}}$ at high $K_{x}$ was gentler than at low $K_{x}$.

Oceanward gradients of $\mathrm{pH}, C_{\mathrm{T}}, A_{\mathrm{T}}$ and $f \mathrm{CO}_{2}$ across lagoons as a result of calcification were observed at Palau Barrier Reef, Majuro Atoll, South Male Atoll (Suzuki et al. 1997; Suzuki and Kawahata 1999), and the Great Barrier Reef (Kawahata et al. 2000). In most cases, the values of $C_{\mathrm{T}}$ in lagoons were lower than those in the adjacent open oceans. Watanabe et al. (2006) observed the two-dimensional vertical profiles of $C_{\mathrm{T}}$ through the Palau barrier reef, and reported decreases from offshore to shore, and also from deep to shallow areas. In the model simulations of this study, $C_{\mathrm{T}}$ also consistently decreased from offshore to shore, and from deep to shallow areas (Fig. 11b, d, f, h).

In conclusion, the results of the modeling described here are supported by some of the reef system phenomena that have been observed in nature. For example, growth rates of coral reefs are generally faster on the windward side than on the leeward side (Hopley and Barnes 1985; Kan et al. 1997; Yamano et al. 2001a). One of the most conspicuous difference between the windward and leeward environments is the level of hydrodynamics. In fact, wind-driven water circulation in coral reefs has been reported by Atkinson et al. (1981) and Yamano et al. (1998). The circulation rate on the windward side, for example, is faster than that on the leeward side, and is considered to be the result of horizontal eddy diffusion. In the computer simulations of this study, reef development was greater when high $K_{x}$ values were used (Fig. 11e-h) because of the greater availability of carbon (high $C_{\mathrm{T}}$ ). The difference in the degree of reef development from the windward to the leeward side of the reef may result from corresponding differences in diffusion rate and carbon supply.

Figure 12 shows the evolution of the reef for the case where $K_{x}=2.5 \times 10^{7} \mathrm{~m}^{2}$ year $^{-1}$. Snapshots of the topography and $C_{\mathrm{T}}$ distribution at 1,000-year intervals between $t=1,000$ and $t=5,000$ years are shown. The following process is evident in the series of simulations. The horizontal surface of the carbonate platform is constructed as sea-level rises over the first 2,000 years (Fig. 12a, c). The $C_{\mathrm{T}}$ gradient from offshore to shore becomes steeper over the first 3,000 years (Fig. 12b, d, f). As a result, the nearshore growth rate of the reef falls (Fig. 12e), and crest-like 
Fig. 11 Morphological changes in coral reef topography (a, c, e, and $\mathbf{g}$ ) and concentration of total carbon dioxide (b, $\mathbf{d}, \mathbf{f}$, and $\mathbf{h}$ ) obtained from simulations varying horizontal diffusion coefficients. Intervals between simulations were 5,000 years (a)

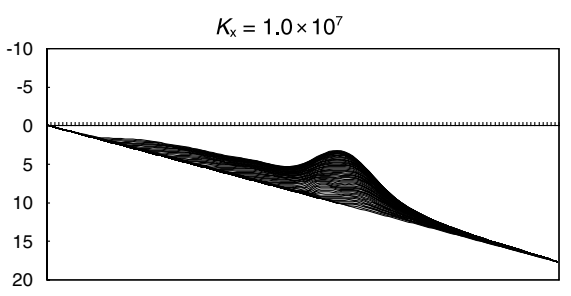

(c)

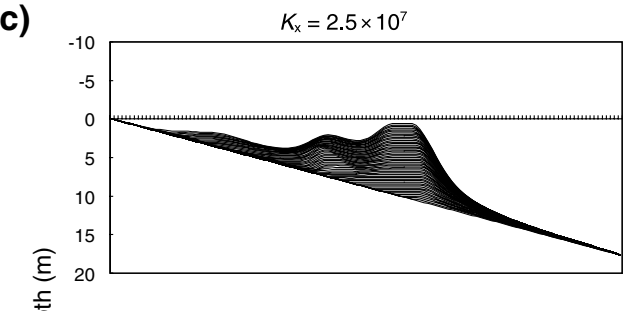

(e)

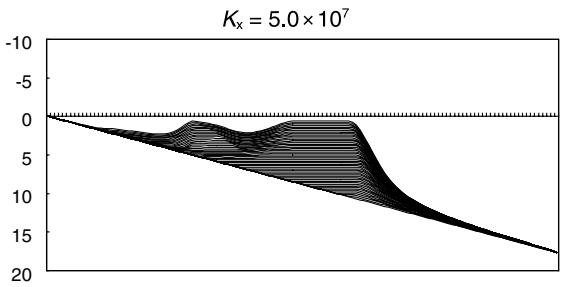

(g)

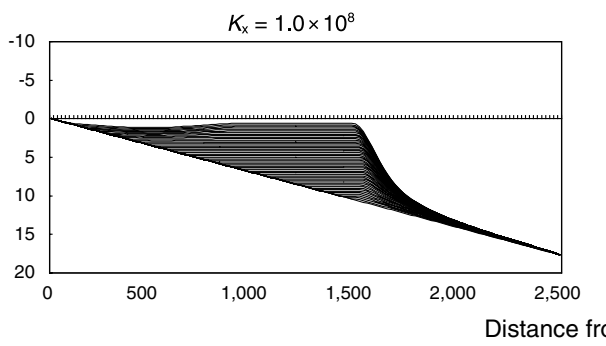

Concentrations of total carbon dioxide $\left(C_{\mathrm{T}}\right)$

(b)

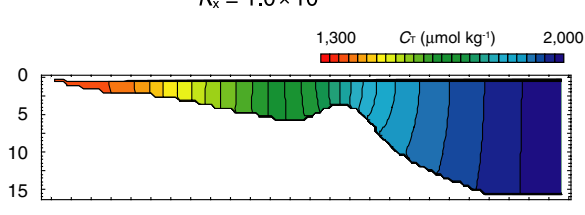

(d)

$K_{\mathrm{x}}=2.5 \times 10^{7}$

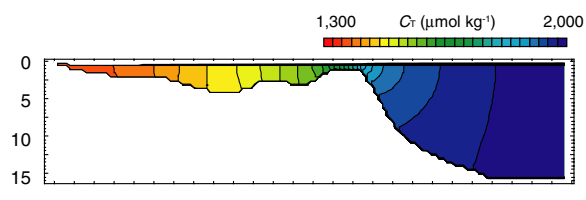

(f) $\quad K_{x}=5.0 \times 10^{7}$

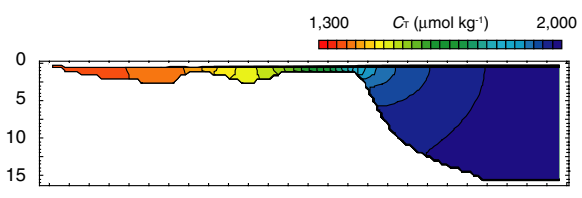

(h)

$K_{\mathrm{x}}=1.0 \times 10^{8}$

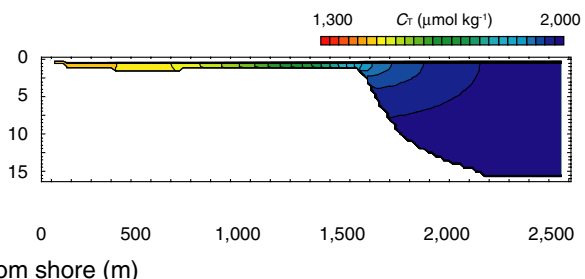

convex structures develop at around 3,000 years and persist in the ensuing years (Fig. 12g). The seaward crest inhibits carbon supply to the moat and the $C_{\mathrm{T}}$ gradient becomes progressively steeper from 4,000 to 5,000 years (Fig. 12h, j). The growth rate of the seaward crest remains high during this period, because this area receives enough light and carbon to maintain rapid growth. At the same time, the growth rate of the moat decreases because of a lower supply of light and carbon. Finally, after 5,000 years, both the seaward crest and the moat are clearly defined as a result of these geochemical processes (Fig. 12i).

Takahashi et al. (1988) reconstructed reef growth during the Holocene sea-level change at Kume Island, in the Ryukyu Islands, on the basis of radiometric ages obtained from core samples. They proposed five phases: (1) the initial reef phase $(7,400-7,000$ years BP), (2) the juvenile phase $(7,000-6,000$ years BP), (3) the crest growth phase $(6,000-5,500$ years BP), (4) the back-reef growth phase $(5,500-5,000$ years BP), and (5) the fore-reef growth phase $(5,000-2,000$ years BP). In their study, reef growth in most areas kept up with the rise in sea level, resulting in a lack of differentiation between the moat and the crest during the phase (1) to the phase (2). A distinct crest developed rapidly during the phase (3), when the moat was also constructed. The sea-level rise has finally stopped, and back-reef and for-reef were developed during the phase (4) to the phase (5). The results of the simulations are almost identical to the phases (1), (2) and (3), when setting of the simulation for sea-level and actual pattern are almost the same. It is also worthy of note that the patterns of reef growth shown in the simulations of this study (Fig. 12) during sea-level rise are very similar to those observed in nature.

This model accurately reconstructed the growth history of the Holocene reef system in Ryukyu Islands. The model, therefore, has potential applications within a range of reef studies in many different geographical contexts. For example, it is considered that the model could be used to reconstruct the Holocene histories of many reef systems worldwide, and the timing of their effects on coastal 
Fig. 12 Evolution of water depth profile and concentration of total carbon dioxide from 1,000 to 5,000 years. The horizontal eddy diffusion coefficient $K_{x}=2.5 \times 10^{7}$ $\left(\mathrm{m}^{2}\right.$ year $\left.^{-1}\right)$ was used for the simulations (a)

Water depth $(h)$

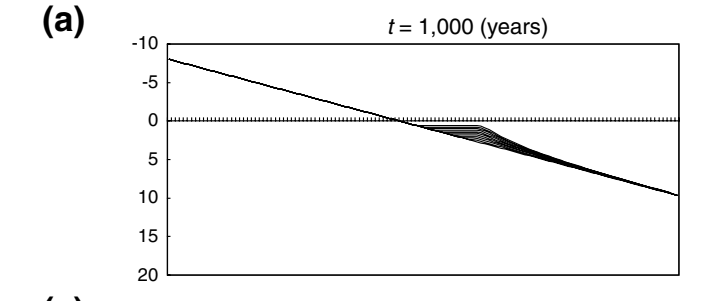

(c)

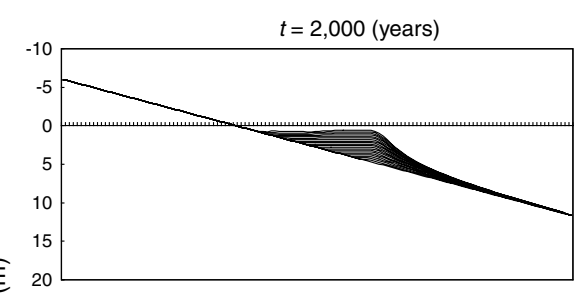

(e) $\frac{F}{\stackrel{\circ}{ \pm}}$

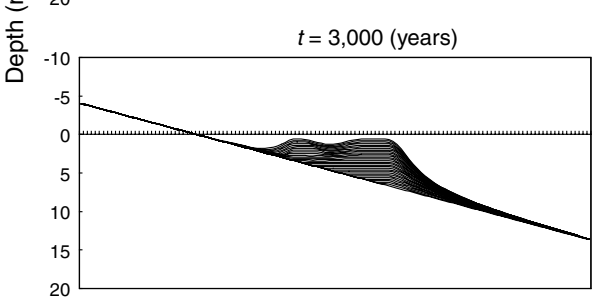

(g)

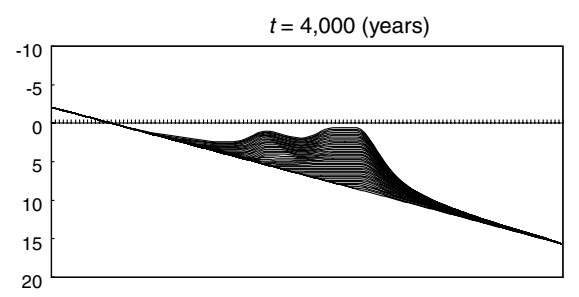

(i)

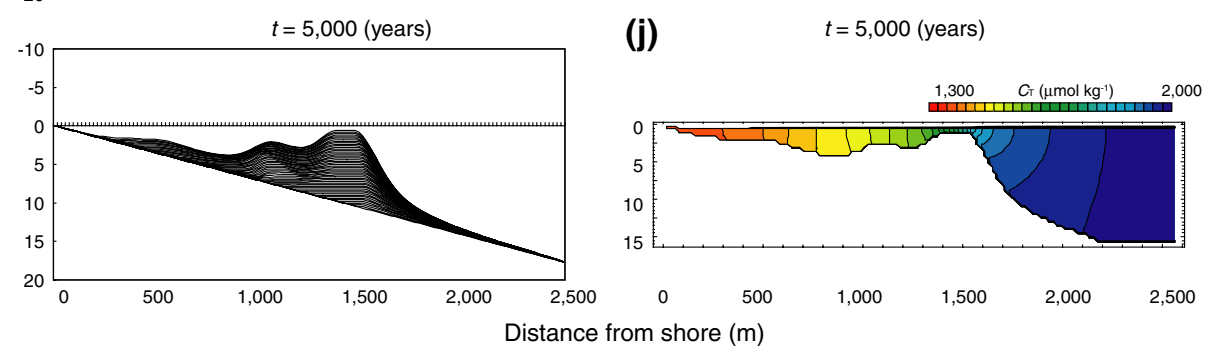

Concentrations of total carbon dioxicide $\left(C_{\mathrm{T}}\right)$

(b) $t=1,000$ (years)

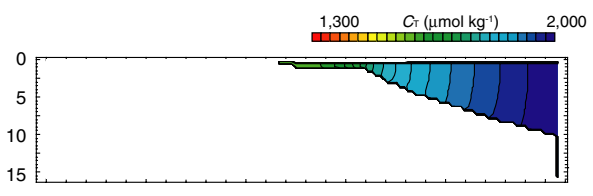

(d) $\quad t=2,000$ (years)
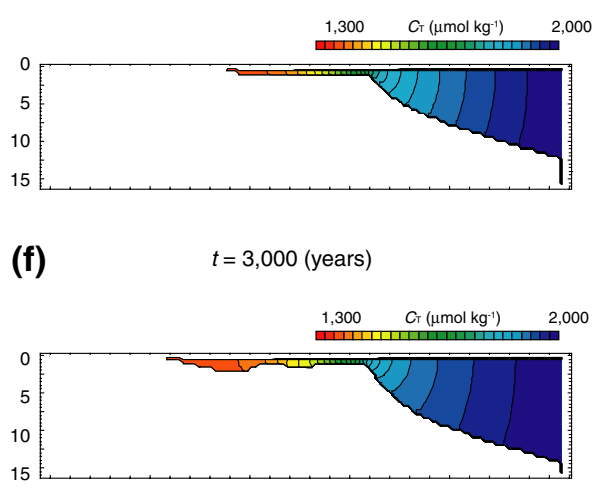

(h) $\quad t=4,000$ (years)

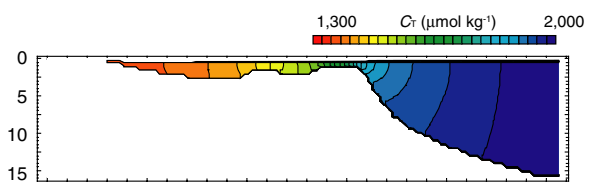

(j) $\quad t=5,000$ (years) hydrodynamics. Or, the geochemical model, together with reef framework and topography, could be used to constrain reconstructions of sea-level history.

\section{References}

Atkinson M, Smith SV, Stroup ED (1981) Circulation in Enewetak Atoll lagoon. Limnol Oceanogr 26:1074-1083

Barnes DJ, Chalker BE (1990) Calcification and photosynthesis in reef-building corals and algae. In: Dubinsky (ed) Coral reefs. Elsevier, Amsterdam, pp 109-131

Barnes DJ, Devereux MJ (1984) Productivity and calcification on a coral reef: a survey using $\mathrm{pH}$ and oxygen electrode techniques. J Exp Mar Biol Ecol 79:213-231

Borowitzka MA (1981) Photosynthesis and calcification in the articulated coralline algae Amphiroa anceps and A. foliaceae. Mar Biol 62:17-23
Borowitzka MA, Larkum WD (1976) Calcification in the green algae Halimeda. III. The source of inorganic carbon for photosynthesis and a model of the mechanism of calcification. J Exp Bot $27: 879-893$

Buddemeier RW, Smith SV (1988) Coral reef growth in an era of rapidly rising sea level: predictions and suggestions for longterm research. Coral Reefs 7:51-56

Chalker BE (1981) Simulating light-saturation curves for photosynthesis and calcification by reef-building corals. Mar Biol 63:135141

Chisholm JRM, Gattuso JP (1991) Validation of alkalinity anomaly technique for investigating calcification and photosynthesis in coral reef communities. Limnol Oceanogr 36:1232-1239

Cortés J, Macintyre IG, Glynn PW (1994) Holocene growth history of an Eastern Pacific fringing reef, Punta IsIotes, Costa Rica. Coral Reefs 13:65-73

Crossland CJ, Hatcher BJ, Smith SV (1991) Role of coral reefs in global ocean production. Coral Reefs 10:55-64 
Culberson CH, Pytkowicz RM (1973) Ionization of water in seawater. Mar Chem 1:309-316

Culberson CH, Pytkowicz RM, Hawley JE (1970) Seawater alkalinity determination by the $\mathrm{pH}$ method. J Mar Res 28:15-21

Culkin F (1965) The major constituents of seawater. In: Riley JP, Skirrow G (eds) Chemical oceanography. Academic Press, New York, pp 121-161

Gao K, Aruga Y, Asada K, Ishihara T, Akano T, Kiyohara M (1993) Calcification in the articulated coralline alga Corallina pilulifera, with special reference to effect of elevated $\mathrm{CO}_{2}$ concentration. Mar Biol 117:129-132

Gattuso JP, Frankignoulle M, Bourge I, Romaine S, Buddemeier RW (1998a) Effect of calcium carbonate saturation of seawater on coral calcification. Global Planet Change 18:37-46

Gattuso JP, Frankignoulle M, Wollast R (1998b) Carbon and carbonate metabolism in coastal aquatic ecosystems. Annu Rev Ecol Syst 29:405-433

Gattuso JP, Allemand D, Frankignoulle M (1999) Photosynthesis and calcification at cellular, organismal and community levels in coral reefs: a review on interaction and control by carbonate chemistry. Am Zool 39:160-183

Gattuso JP, Reynaud-Vaganay S, Furla P, Romaine-Lioud S, Jaubert J, Bourge I, Frankignoulle M (2000) Calcification does not stimulate photosynthesis in the zooxanthellate scleractinian coral Stylophora pistillata. Limnol Oceanogr 45:246-250

Goreau TF (1959) The physiology of skeleton formation in corals. I. A method for measuring the rate of calcium deposition by corals under different conditions. Biol Bull 116:59-75

Goreau TF, Goreau NI (1959) The physiology of skeleton formation in corals. II. Calcium deposition by hermatypic corals under various conditions in the reef. Biol Bull 117:239-250

Hopley D, Barnes R (1985) Structure and development of a windward fringing reef, Orpheus Island, Palm Group, Great Barrier Reef. Proc 5th Int Coral Reef Symp 3:141-146

Kan H, Hori N (1993) Formation of topographic zonation on the welldeveloped fringing reef-flat, Minna Island, the Central Ryukyus. Transactions Japanese Geomorphological Union 14:1-16

Kan H, Hori N, Nakashima Y, Ichikawa K (1995) The evolution of narrow reef flats at high-latitude in the Ryukyu Islands. Coral Reefs 14:123-130

Kan H, Hori N, Kawana T, Kaigara T, Ichikawa K (1997) The evolution of a Holocene fringing reef and island: Reefal environmental sequence and sea level change in Tonaki Island, the Central Ryukyus. Atoll Res Bull 443:1-20

Kawahata H, Suzuki A, Ayukai T, Goto T (2000) Distribution of the fugacity of carbon dioxide in the surface seawater of the Great Barrier Reef. Mar Chem 72:257-272

Kayanne H, Yamano H, Randall RH (2002) Holocene sea-level changes and barrier reef formation on an oceanic island, Palau Islands, western Pacific. Sediment Geol 150:47-60

Kennedy DM, Woodroffe CD (2000) Holocene lagoonal sedimentation at the latitudinal limits of reef growth, Lord Howe Island, Tasman Sea. Mar Geod 169:287-304

Kinsey DW (1977) Seasonality and zonation in coral reef productivity and calcification. Proc 3rd Int Coral Reef Symp 2:382-388

Konishi K, Tsuji Y, Goto T, Tanaka T, Futakuchi K (1983) Multi-hole shallow drilling of coral reefs-a case history of the Holocene in Kikai Island, central Ryukyus. Monthly Marine Science 15:154 164

Langdon C, Takahashi T, Sweeney C, Chipman D, Goddard J (2000) Effect of calcium carbonate saturation state on the calcification rate of an experimental coral reef. Global Biogeochem Cycles 14:639-654

Leclercq N, Gattuso JP, Jaubert J (2000) $\mathrm{CO}_{2}$ partial pressure controls the calcification rate of a coral community. Global Change Biol 6:329-334
Leclercq N, Gattuso JP, Jaubert J (2002) Primary production, respiration, and calcification of a coral reef mesocosm under increased $\mathrm{CO}_{2}$ partial pressure. Limnol Oceanogr 47:558-564

Lucas WJ (1975) Photosynthetic fixation of ${ }^{14}$ Carbon by internodal cells of Chara corallina. J Exp Biol 26:331-346

Lyman J (1957) Buffer mechanism of sea water. PhD Thesis, University of California, Los Angeles, p 198

Marshall JF, Davies PJ (1982) Internal structure and Holocene evolution of One Tree Reef, Southern Great Barrier Reef. Coral Reefs 1:21-28

Martin S, Castets MJ, Clavier J (2006) Primary production, respiration and calcification of the temperate free-living coralline algae Lithothamnion corallioides. Aquat Bot 85:121-128

Marubini F, Atkinson M (1999) Effects of lowered pH and elevated nitrate on coral calcification. Mar Ecol Prog Ser 188:117-121

Marubini F, Thake B (1999) Bicarbonate addition promotes coral growth. Limnol Oceanogr 44:716-720

Mehrbach C, Culberson H, Hawley E, Pytkowicz M (1973) Measurement of the apparent dissociation constants of carbonic acid in seawater at atmospheric pressure. Limnol Oceanogr 18:897-907

Montaggioni LF (2005) History of Indo-Pacific coral reef systems since the last glaciation: development patterns and controlling factors. Earth-Sci Rev 71:1-75

Montaggioni LF, Faure G (1997) Response of reef coral communities to sea-level rise: a Holocene model from Mauritius (western Indian Ocean). Sedimentology 44:1053-1070

Nakamori T (1986) Community structures of recent and Pleistocene hermatypic corals in the Ryukyu Islands, Japan. Tohoku University Science Report, 2nd series (Geology) 56:71-133

Nakamori T, Suzuki A, Iryu Y (1992) Water circulation and carbon flux on Shiraho coral reef of the Ryukyu Islands, Japan. Cont Shelf Res 12:951-970

Nakamura T, Nakamori T (2006) Population dynamics of hermatypic coral communities on reef slope vs. reef flat at Shiraho, Ishigaki Island, southwest Japan. Proc 10th Int Coral Reef Symp 460-477

Odhe S, van Woesik R (1999) Carbon dioxide flux and metabolic processes of a coral reef, Okinawa. Bull Mar Sci 65:559-576

Odum HT, Odum EP (1955) Trophic structure and productivity of windward coral reef community on Enewetok Atoll. Ecol Monogr 25:292-320

Riebesell U, Wolf-Gladrow DA, Smetacek V (1993) Carbon dioxide limitation of marine phytoplankton growth rate. Nature 361:249_ 251

Scheidegger AE (1970) Theoretical geomorphology. 2nd edn Springer, New York

Smith SV, Key GS (1975) Carbon dioxide and metabolism in marine environments. Limnol Oceanogr 20:493-495

Smith SV, Kinsey DW (1978) Calcification and organic carbon metabolism as indicated by carbon dioxide. In: Stoddart DR, Johannes RE (eds) Coral reefs: research methods. UNESCO, pp $469-484$

Suzuki A, Kawahata H (1999) Partial pressure of carbon dioxide in coral reef lagoon waters: comparative study of atolls and barrier reefs in the Indo-Pacific Oceans. J Oceanogr 55:731-745

Suzuki A, Nakamori T, Kayanne H (1995) The mechanism of production enhancement in coral reef carbonate system: model and empirical results. Sediment Geol 99:259-280

Suzuki A, Kawahata H, Goto K (1997) Reef water $\mathrm{CO}_{2}$ system and carbon cycle in Majuro Atoll, the Marshall Islands in the central Pacific. Proc 8th Int Coral Reef Symp 1:971-976

Takahashi T, Koba M, Kan H (1988) Relationship between reef growth and sea level on the Northwest coast of Kume Island, the Ryukyus: data from drill holes on the Holocene coral reef. Proc 6th Int Coral Reef Symp 3:194-196 
Watanabe A, Kayanne H, Hata H, Kudo S, Nozaki K, Kato K, Negishi A, Ikeda Y, Yamano $\mathrm{H}$ (2006) Analysis of the seawater $\mathrm{CO}_{2}$ system in the barrier reef-lagoon system of Palau using total alkalinity-dissolved inorganic carbon diagram. Limnol Oceanogr 51:1614-1628

Yamano H, Kayanne H, Yonekura N, Nakamura H (1998) Water circulation in a fringing reef located in a monsoon area: Kabira Reef, Ishigaki Island, southwest Japan. Coral Reefs 17:89-99

Yamano H, Abe O, Kitagawa H, Niu E, Nakamura T (2001a) Coral reef evolution at the leeward side of Ishigaki Island, southwest Japan. Radiocarbon 43:899-908
Yamano H, Kayanne H, Yonekura N (2001b) Anatomy of a modern coral reef flat: a recorder of storms and uplift in the late Holocene. J Sediment Res 71:295-304

Yamashiro H (1995) The effects of HEBP, an inhibitor of mineral deposition, upon photosynthesis and calcification in the scleractinian coral, Stylophora pistillata. J Exp Mar Biol Ecol 191:57-63

Yonekura N, Kayanne H, Matumoto E, Ishii T, Matushima Y, Hori N, Nakai T (1994) Geomorphic development of modern fringing reef of Yoron Island, Ryukyu Arc, Japan. Quat Res (Tokyo) 33:67-79

Zimmerman RC, Kohrs DG, Steller DL, Alberte RS (1997) Impacts of $\mathrm{CO}_{2}$ enrichment on productivity and light requirements of eelgrass. Plant Physiol 115:599-601 